\title{
Predictors of Intention to Provide Halal Maintenance
}

\author{
Sa'odah Ahmad, Mohammad Arif Johari, Rojanah Kahar, Muslihah Hasbullah
}

\begin{abstract}
This study examined the relationship between attitude, subjective norms and perceived behavioral control with the intention to provide halal maintenance to the family among Muslim fathers in Malaysia. The participants comprised of 353 Muslim fathers. The data were collected via a self-administered questionnaire. Findings from the study showed that there was a positive relationship between attitude, subjective norms and perceived behavioral control with the father's intention to provide halal maintenance for the family. In addition, the subjective norm is proven to be the most significant predictor of the intention to provide halal maintenance for the family.
\end{abstract}

Index Terms: Attitude, Subjective Norms, Perceived Behavioral Control, Intention, Halal Maintenance.

\section{INTRODUCTION}

The foundation of human civilization and the integrating factors of society's orders are constituted by the proper functioning of the family. Specific rules for the formation and proper functioning of the family are provided by laws. As far as family matters are concerned, Muslim jurists agreed that the protection of lineage and preservation of family values were undeniably the goals of Islamic law (maqasid al Shariah) as a whole. Islamic law has a deep tradition of concepts relating to rights and obligation and it contemplates the role of faith and injunctions evenly important in the performance of an obligation.

The family is the core of the civilization and the establishment of a legal marriage is the mainstay of the family formation in Islam which must be sustained in agreement with the Shariah. In a practical facet, Islamic marriage is thus structured via legally enforceable rights and obligations of the spouses. In an ecosystem of love and respect, these rights and duties stipulate a context for the stability of family life and the contentment of the married couple. Islam focuses immense attention to the family commencement, providing it preservation, ensuring that family is a source for comfort and relaxation, strengthening the relationship between the husband and wife and protecting the next generation.

Revised Manuscript Received on September 22, 2019

Sa'odah Ahmad, Department of Human Development and Family Studies, Faculty of Human Ecology, Universiti Putra Malaysia, Missing Email

Mohammad Arif Johari, Department of Human Development and Family Studies, Faculty of Human Ecology, Universiti Putra Malaysia

Rojanah Kahar, Department of Human Development and Family Studies, Faculty of Human Ecology, Universiti Putra Malaysia

Muslihah Hasbullah, Department of Human Development and Family Studies, Faculty of Human Ecology, Universiti Putra Malaysia.
The association of husband and wife and outlining their mutual rights and duties are the substance of family life. Both husband and wife have been dispensed with explicit roles and function to safeguard the functioning of a happy and blessed family. The notion of partnership between husband and wife or father and mother in constructing an Islamic (halal) family is very much accentuated in Islam. One of the principal obligations of a man/husband is to provide halal maintenance to his dependents.

Providing maintenance to the family is obligatory of a father and has been sanctioned by various verses (ayat) in the Qur'an as well as hadith of the Prophet Muhammad S. A. W. In Surah al-Nisa'(3): 34 which states to the effect:

"Men are the protectors and maintainer of women because Allah has given the one more strength than the other and because they support them from their means."

In one hadith narrated by Jabir (R.A), the Rasulullah S.A.W in his final sermon said:

"Fear Allah concerning women! Verily you have taken them on the security of Allah, and intercourse with them has been made lawful unto you by words of Allah. You too have right over them, and that they should not allow anyone to sit on your bed whom you do not like. But if they do that, you can chastise them but not severely. Their rights upon you are that you should provide them with food and clothing in a fitting manner. I have left among you the Book of Allah, and if you hold fast to it, you would never go astray."[1]

These authorities put the total weight of maintenance of a wife (as well as family) on the husband whatever the wife own wealth and earnings may be. They also become the common standard to Muslims throughout the world on the duties assigned to men in the framework of family maintenance. In addition, the provision of maintenance (nafaqah) by a husband to the family is a duty that must be accomplished and has been enacted in the Islamic Family Law in Malaysia [2-4].

It is the primary obligation of parents (especially fathers) to organize for appropriate and halal maintenance, the suitable type of education, and respectable guidance to their children so that they mature satisfactorily, develop their potential, articulate their knacks, become an honorable individual, an upright citizen. The Islamic family law in Malaysia specifies that the court may, subject to hukum syara', command a husband to provide maintenance for the family.

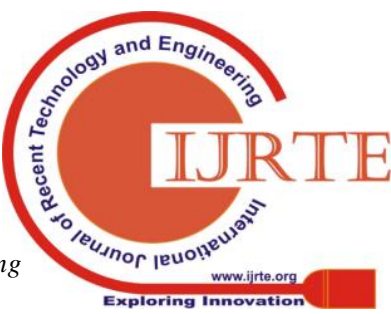


Nevertheless, a wife will not be entitled to maintenance if she is nusyuz or irrationally declines to conform to the lawful needs or orders of her husband (Section 59 of the Islamic Family Law Act (Federal Territories) 1984 (IFLA 1984).

As for the maintenance of children by the father, it is provided in section 72 of IFLA 1984. The responsibility of the father to provide for his children does not end with a divorce or whether or not he has custody of them or whether the children have reached majority age. In the case of Sharifah Sapoyah v Wan Alwi (1989) 2 JH 259, the court held that the father must maintain his three children until they reach 18 years old. Furthermore, section 79 of IFLA 1984 provides that the court has the power to extend the financial support until the child completed his tertiary education. Parental responsibilities are one of the important regimes that have been identified by Islamic law as it connotes legal and moral obligation throughout children life.

Section 61 of IFLA 1984 provides that: "In determining the amount of any maintenance to be paid, the Court shall base its assessment primarily on the means and needs of the parties, regardless of the proportion the maintenance bears to the income of the person against whom the order is made". A similar provision can be found in other Islamic Family Law Enactments in Malaysia such as in Selangor Islamic Family Law Enactments 2003 as provided for under section 6. It has been an established rule of the Islamic law that providing financial support is considered as a religious obligation and can be legally enforceable.

Attitude toward behavior envisages both the favorable and unfavorable aspects of the targeted behavior [5]. In ascertaining the foremost component for comprehending human behavior as it relates to intention, the attitude remains the central feature [6]. This means that an individual's main beliefs about certain behavior determine the attitude toward the behavior. Past studies showed that there is a significant and positive association among attitude and intentions to purchase halal products [7, 8].

Many Muslim husbands/fathers had no clear knowledge of the meaning of maintenance (nafqah) and the duties to provide it [9]. Some husbands/fathers even have a negative attitude and feel that there was no duty to maintain a working wife as the wife has her own life resources. Failure to perform these husbandly/fatherly duties led to the application by the wives for her maintenance as well as the children to the Shariah Courts in Malaysia [10].

Sadly, there are cases where despite the court's order for fathers to pay maintenance and child support after a divorce, the fathers obstinately uphold negative attitude with regards to such duties to the extent that they dare refused to comply with the court's order [10-12]. This malpractice inadvertently caused financial hardship to the single mothers who were given the rights of custody upon divorce. Furthermore, the reluctances of a non-custodial father to establish contact with his children further aggravate the issue of non-payment of maintenance of the children after divorce.

Subjective norm is the function of beliefs or perceived social pressure/expectation that stipulates a person's thinking about the appropriateness of an action or behavior by his significant others or any social groups that he is belong to. Previous studies in Malaysia proves the positive relationship between subjective norms and intention [7, 8]. Thus, the subjective norm in Malaysia plays an essential role where family members, friends, and associates are a person's source of reference and advice.

Ajzen [5] asserted that perceived behavioral control is governed by the person's beliefs about the power of both situational and internal factors to ease the performing of the behavior. This means that the greater the control and the personal experience and feel about an action, the more likely he or she will do the action. A study by Abdullah et al. [13] revealed that there is a positive effect of attitude, subjective norms and perceived behavioral control on recycling intention.

The father's behavior in providing halal maintenance is a part of his explicit behavior. The Theory of Planned Behaviour $^{5}$ is one of the most influential models in predicting human behavior and behavioral natures. This theory posits that intention influences behavior. Attitudes (evaluation of the behavior as confirmatory or unfavorable), subjective norm (perceptions of social strain or anticipations), and perceived behavioral control (perceived hardship or ease in conveying out the behavior) are believed to be predictors of human intentions.

There was no previous study that examined the association among attitude, subjective norms and behavioral control with the intention to provide halal maintenance to the family. The closest study of this nature was the intention to purchase the halal product [14-16] and compliance intention to pay zakat. [17] Therefore, the present study was conducted to determine the association between attitude, subjective norms and perceived behavioral control with the intention to provide halal maintenance to the family among Muslim fathers in Malaysia.

\section{METHODS}

\section{A. Research Design}

This study employed a correlational design and quantitative approach in examining the association $b$ among attitude, subjective norms and perceived behavioral control with the intention to provide halal maintenance to the family.

\section{B. Participants and Procedures}

The study was conducted in Kedah, Johor, Selangor, and Terengganu, which represent the geographical zone in Peninsular Malaysia. The total number of participants was 353. The participants were married Muslim man working in the public sectors. The participants were selected randomly from the list of names provided by the human resource department in the chosen agencies.

\section{Published By:} Blue Eyes Intelligence Engineering 
The participants participated in the study voluntarily and they were informed about the confidential nature of the study. The questionnaires were self-administered.

\section{MEASURES}

\section{A. Attitude}

The attitude on the responsibility to provide halal maintenance was measured by an adaptation of the Halal Haram Consumer Index by Nor Aini and Mohd Ali.[18] The scale consisted of six items. An example of an item - 'For me, it is important to provide halal maintenance to the family' and 'I always strive to provide halal maintenance to my family'. The responses were valued on a 4-point level: $1=$ strongly disagree to $4=$ strongly agree. For this study, the alpha coefficient for attitude was 0.91 which indicated a good internal consistency of the scale.

\section{B. Subjective Norms and Perceived Behavioural Control}

Subjective norms and behavioral control were measured using an adaptation of the Intention Scale by Fishbein and Ajzen. ${ }^{5}$ There are six items measuring subjective norms and five items to measure perceived behavioral control. An example of an item: "People who are most important to me think that I should provide for halal maintenance to my family"; "I have control on whether or not I would be able to provide halal maintenance to my family". For this study, the alpha coefficient for subjective norms and perceived behavioral control were 0.91 and 0.67 which indicated a good internal consistency of the scales.

\section{Intention to provide halal maintenance}

An adaptation of the Intention Scale by Fishbein and Ajzen was used to measure intention to provide halal maintenance [5]. The scale consisted of 3 items. An example of an item - 'I plan to provide for halal maintenance to my family'. The answers were valued on a 4-point level: $1=$ strongly disagree to $4=$ strongly agree. For this study, the alpha coefficient for the intention was 0.64 .

\section{Socio-demographic characteristics.}

Participants answered questions on demographics pertaining to age, number of years of marriage, years of education, income, and number of children.

\section{E. Data Analyses}

Descriptive analysis was performed to give a clearer picture of the data dispersal. In addition, exploratory data analysis was conducted to determine whether the inferential statistical methods chosen achieved the basic suppositions in terms of the normal dispersal of population, linearity among the dependent variable and the independent variables. The extent and intensity of the relationship of the investigated variables were quantitatively quantified using Pearson product-moment correlations. Lastly, multiple regressions were used to determine the unique predictor of the dependent variable.

\section{RESULT}

\section{A. Socio-Demographics Attributes}

The mean age of the participants was 38.4 years old $(\mathrm{SD}=$ 9.7). They completed about 13 years of formal education (SD $=1.9)$ and had been married for about 11 years $(\mathrm{SD}=9.6)$. In term of income, the participants had an average income of RM2458.11 (SD = RM1082.30). They have an average number of children at 2.53 which are slightly below the common size of the Malaysian family of 2.76 as reported in the Ninth Malaysian Plan 2006-2010.

\section{B. Attitude, Subjective Norms and Perceived Behavioral Control}

In term of attitude on the responsibility to provide halal maintenance, most $(68.6 \%, 242)$ participants were categorized in the high level, followed by $24.0 \%(n=86)$ in the low level and the remaining $7.1 \%(n=25)$ in moderate level. As regards to subjective norms, the percentage of the participants informed having a high and low level of subjective norms is equal at $42.8 \%$. The remaining $14.4 \%$ of the participants reported having a moderate level of subjective norms. In term of perceived behavioral control, $40.2 \%$ of the participants were categorized in the low level followed by $36.5 \%$ in the high level and $23.2 \%$ in the moderate level. Finally, Table 1 depicted that most $(58.9 \%$, $\mathrm{n}=208$ ) participants reported of having a high level of intention to provide halal maintenance to the family followed by $31.2 \%(n=110)$ having a low level and $9.9 \%$ $(n=35)$ having a moderate level.

Table 1: The level of attitude, and intention to provide halal

\begin{tabular}{lcc}
\hline Variables (score) & n & \% \\
\hline Attitude & 86 & 24.4 \\
Low $(<18)$ & 25 & 7.1 \\
Moderate (18-19) & 242 & 68.6 \\
High $(\geq 20)$ & & \\
Subjective Norm & 151 & 42.8 \\
Low $(<21)$ & 51 & 14.4 \\
Moderate $(21-23)$ & 151 & 42.8 \\
High $(\geq 24)$ & & \\
Perceived Behavioral Control & 142 & 40.2 \\
Low $(<16)$ & 82 & 23.2 \\
Moderate (16-18) & 129 & 36.5 \\
High $(\geq 19)$ & & \\
Intention to provide halal & & \\
maintenance for the family & 110 & 31.2 \\
Low $(<10)$ & 35 & 9.9 \\
Moderate (10-11) & 208 & 58.9 \\
High ( $\geq 12)$ & & \\
\hline
\end{tabular}

C. The association between Attitude Subjective Norms, Perceived Behavioral Control and Intention to Provide Halal Maintenance

Table 2 shows the findings of Pearson Correlation test which was carried out to determine the correlation between the father's attitude, subjective norms and perceived behavioral control with the intention to provide halal

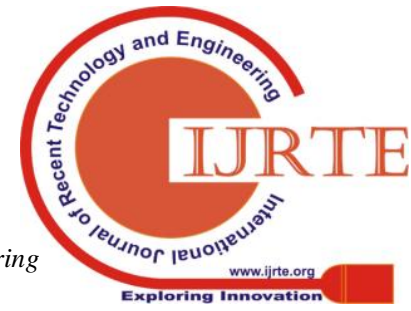


maintenance to the family. The table revealed that the father's attitude, subjective norms, and perceived behavioral control significantly associated with the intention to provide halal maintenance for the family. The value indicated for attitude is $(\mathrm{r}=0.289, \mathrm{p}<0.001)$, subjective norm $(\mathrm{r}=0.491$, $\mathrm{p}<0.001)$ and perceived behavioural control $(\mathrm{r}=0.462$, $\mathrm{p}<0.001)$.

Table 2: Pearson Correlation between Variables

\begin{tabular}{lcc}
\hline Variables & \multicolumn{2}{c}{$\begin{array}{l}\text { Intention to } \\
\text { Maintenance for the Family }\end{array}$} \\
\cline { 2 - 3 } & $\mathbf{r}$ & $\mathbf{p}$ \\
\hline Attitude & $.289^{* * *}$ & .000 \\
Subjective Norm & $.491 * * *$ & .000 \\
Perceived & $.462 * * *$ & .000 \\
Behavioural Control & &
\end{tabular}

Note: $* * *$ Level of significant is at $\mathrm{p}<0.001$

\section{Unique Predictor of Intention to Provide Halal Maintenance}

Table 3 revealed findings based on the multiple regression analysis on factors that can predict the father's intention to provide halal maintenance to the family. The data showed that subjective norm $(\beta=0.297, \quad \mathrm{p}=0.000)$, perceived behavioral control $(\beta=0.270, \quad \mathrm{p}=0.000)$, and attitude $(\beta=0.077, p=0.217)$ are significant predictors of father's intention to provide halal maintenance for the family. The significance was explained by $30.7 \%$ of the variance in the intention to provide for halal maintenance. Among these predictors, the subjective norm is proven to be the most significant predictor to intention to provide halal maintenance for the family.

Table 3: Multiple Regression Analysis for Unique Predictor of Intention to Provide Halal Maintenance.

\begin{tabular}{lccc}
\hline Variable & \multicolumn{3}{l}{$\begin{array}{l}\text { Intention to Provide Halal } \\
\text { Maintenance for the Family }\end{array}$} \\
\cline { 2 - 4 } & B & SE.B & Beta, $\beta$ \\
\hline Attitude & .065 & .053 & .077 \\
Subjective Norm & .147 & .029 & $.297 * * *$ \\
Perceived & .160 & .032 & $.270^{* * *}$ \\
Behavioural Control & & & \\
Adjusted $\boldsymbol{R}^{2}$ & .307 & & \\
$\boldsymbol{F}$ & $32.156 * * *$ \\
\hline Note: Intention to Provide Halal Maintenance for the Family \\
F (5,347) = 32.156 \\
*** Level of significant is at $\mathrm{p}<.001$
\end{tabular}

\section{DISCUSSION AND CONCLUSION}

This study provides a foundation for future research pertaining to the correlation among attitude, subjective norms and perceived behavioral control with the Malaysian Muslim father's intention to provide halal maintenance to the family. Results revealed that there was a positive correlation among attitude, subjective norms and perceived behavioral control with the father's intention. This means that when the level of attitude, subjective norms and perceived behavioral control on the responsibility to provide for halal maintenance among fathers increases, the level of intention to fulfill the responsibility will correspond to it.

Thus, this study is in line with the Theory of Planned Behavior $^{5}$ which proposed that behavior or actions are influenced by intentions. Moreover, attitudes, subjective norm, and perceived behavioral control are proven as predictors of intentions. The study is also confirming past researches which investigate factors that influence the intention for various actions. ${ }^{7,8,16}$

As there is no previous study specifically conducted in Malaysia assessing the association between attitudes, subjective norms and perceived behavioral control with the intention of Muslim fathers to provide halal maintenance, findings of this study are very significant as they provide the set of data on the issue. Most importantly, this study has effectively filled the research gap pertaining to the evaluation of a Muslim father's intention to provide halal maintenance to the family in Malaysia.

There are several shortcomings to the current study. Firstly, the conclusion about the direction of effects regarding the association between attitude, subjective norms and perceived behavioral control and intention to provide halal maintenance cannot be generalized to other population as a result of the cross-sectional nature of the data retrieved. Secondly, the validity and reliability of the obtained information depended solely on the integrity of the respondents as the data were gathered by self-administered questionnaire.

\section{ACKNOWLEDGMENT}

This study was supported by the research fund provided under Geran Putra IPB scheme by the Universiti Putra Malaysia.

\section{REFERENCES}

[1] Hadith - The Book of Pilgrimage - Sahih Muslim - Sunnah.com - Sayings and Teachings of Prophet Muhammad S.A.W [Internet]. Sunnah.com. 2019 [cited 19 April 2019]. Available from: https://sunnah.com/muslim/15/159.

[2] Najibah MZ, Nora AH, Azizah M, Normi AM, Norliah I, Roslina CSY et al. Islamic Family Law in Malaysia. Selangor: Sweet \& Maxwell. 85 p.

[3] Ahmad I. Undang-undang Keluarga Islam di Malaysia. Kuala Lumpur: Malayan Law Journal Sdn Bhd; 1999. 180 p.

[4] Kamariah M. Family Law in Malaysia. Kuala Lumpur: Malayan Law Journal Sdn Bhd; 1999. 340 p.

[5] Ajzen I. The theory of planned behavior. Organizational Behavior and Human Decision Processes. 1991;50(2):179-211.

[6] Ajzen I, Fishbein M. The influence of attitudes on behavior. In: Albarracin D, Johnson BT, Zanna MP editors. The Handbook of Attitudes. NJ: Erlbaum; 2005. p.173-221.

[7] Ummi Naiemah SA. Examining the relationship between attitude towards behaviour, subjective norms and entrepreneurial intention among engineering students [Internet]. 2018 [cited 18 April 2019]. Available from: https://www.matecconferences.org/articles/matecconf/pdf/2018/09/mate cconf_mucet2018_05011.pdf.

[8] Noor AA, Farah LA, Aflah ID. Determinants of halal purchase intention: Case in Perlis. IJBSR. 2014, 4:5:118-123.

[9] Najibah MZ. Siri Perkembangan Undang-undang di Malaysia: Undang-undang keluarga (Islam). Kuala Lumpur: Dewan Bahasa dan Pustaka; 2007. 155 p. 
[10] Zainoor RK. Hak Kanak-kanak dari aspek nafkah: Perintah mahkamah, perlaksanaan dan permasalahan. In Najibah MZ editor, Undang-undang keluarga dan prosedur, Siri isu Mahkamah Syariah. Gombak: Harun Hashim Law Centre, IIUM. 2009. p.149-161.

[11] Zaleha KR. A preliminary study on no-custodial father's contact with their children after divorce in Malaysia. IKIM Law Journal. 2005:177-200.

[12] Norasmaliah I. Hubungan bapa-anak selepas perceraian. [Undergraduate]. Universiti Putra Malaysia; 2000.

[13] Abdullah AM, Muhammad M, Ghazali A, Thurasamy R, Syed Ali F. Recycling intention and behavior among low-income households [Internet]. Sustainability. 2018 [cited 18 April 2019]. Available from: https://www.academia.edu/37176249/Recycling_Intention_and_Behav ior_among_Low-Income_Households.

[14] Hayat MA, Ahmad NS, Zeeshan H. Factors affecting halal purchase intention - Evidence from Pakistan's halal food sector. Management Research Review. 2012; 38(6): 640-660.

[15] Haslenna H, Zuraini MI, Normala A, Kamaruzaman J. Purchasing decisions among Muslim consumers of processed halal food products. Journal of Food Products Marketing. 2013;19(1): 54-61.

[16] Nur HLA. Intention to purchase halal product among consumers [Internet]. Etd.uum.edu.my. 2011 [cited 18 April 2019]. Available from: http://etd.uum.edu.my/2790/2/1.Nur_Haslizatul_Liza_Ahmad.pdf.

[17] Farah MNA, Zainol B. Factors influencing zakat compliance behavior on saving. IJBSR. 2015;05(01):118-128.

[18] Nor Aini I, Mohd Ali MN. Analisis keprihatinan pengguna Muslim terhadap isu halal-haram produk melalui pembentukan Indeks Halal Haram. Persidangan Kebangsaan Ekonomi Malaysia ke V111 [Internet]. Johor Bahru: UKM; 2013 [cited 18 April 2019].p.1256.Availablefrom:http://www.ukm.my/fep/perkem/pdf/perke mVIII/PKEM2013_4F5.pdf.

\section{AUTHORS PROFILE}

My good name is Sa'odah Ahmad, currently I am affiliated with Department of Human Development and Family Studies, Faculty of Human Ecology, Universiti Putra Malaysia. My area of interest is Human behavior and Psychology.

I am Mohammad Arif Johari, my current affiliation is Department of Human Development and Family Studies, Faculty of Human Ecology, Universiti Putra Malaysia. My interest is Human development.

My name is Rojanah Kahar, my current affiliation is with Department of Human Development and Family Studies, Faculty of Human Ecology, Universiti Putra Malaysia. My area of interest is Development and knowledge learning.

My name is Muslihah Hasbullah, affiliated with Department of Human Development and Family Studies, Faculty of Human Ecology, Universiti Putra Malaysia. My area of interest is Human development. 